\title{
Assessment of Displacement Flow at Ketandan Creeks to Optimizing Land Use in Jember New City Housing
}

\author{
Entin Hidayah ${ }^{1}$, Wiwik Yunarni Widiarti ${ }^{1}$, and Anik Ratnaningsih ${ }^{1}$
}

\begin{abstract}
Displacement flow will caused a change in the flow characteristics such as flow depth, discharge, river slope and width of the river surface. If not carefully examined, it will cause the riverbed erosion, sedimentation and risk of flooding. This paper aims to assess the hydrology and hydraulics of the river flow changes in Ketandan creek in optimizing the use of land housing for Jember New City (JNC). Hydrology modelling studies conducted for the return period rainfall include a 2 year as normal discharge, and 100 year as flood condition. Simulation of flood designs used to assess changes in the flow regime in the channel and the risk of flooding with HEC-RAS program. The results of the study showed that for the flood design $3,1 \mathrm{~m}^{3} / \mathrm{sec}$ and $12,8 \mathrm{~m}^{3} / \mathrm{sec}$ will give the effect of critical water surface. In order to keep the flow of the river bed of critically needed as the drop-structure and spillway construction.
\end{abstract}

Keywords— displacement flow, critical, water surface.

Abstrak - Aliran perpindahan akan menyebabkan perubahan karakteristik aliran seperti kedalaman aliran, debit, kemiringan sungai dan lebar permukaan sungai. Jika tidak diperiksa dengan teliti, maka akan menyebabkan erosi sungai, sedimentasi dan risiko banjir. Tulisan ini bertujuan untuk menilai hidrologi dan hidrolika dari perubahan aliran sungai di Ketandan sungai dalam mengoptimalkan penggunaan lahan untuk perumahan Jember New City (JNC). Studi pemodelan hidrologi dilakukan untuk curah hujan periode ulang mencakup 2 tahun sebagai debit normal, dan 100 tahun sebagai kondisi banjir. Simulasi desain banjir digunakan untuk menilai perubahan rezim aliran dalam saluran dan risiko banjir program HEC-RAS. Hasil penelitian menunjukkan bahwa untuk desain banjir 3,1 m3 / detik dan 12,8 m3 / detik akan memberikan efek permukaan air kritis. Dalam rangka menjaga aliran sungai kritis diperlukan sebagai drop-struktur dan konstruksi pelimpah.

Kata Kunci-aliran perpindahan, kritis, permukaan air.

\section{INTRODUCTION}

$\mathrm{T}$ he growth of a city will require the expansion of residential land. Land used as residential expansion area sometimes sacrificing rice plant, upland and stream converted to housing. It occurred in Jember town, the land use to produce rice and now change housing such as Bumi Kaliwates, Griya Mangli, Mandiri Land, Muktisari etc. During high intensity rainfall is flooding. This is caused by the loss location puddles, or water infiltration and a decrease in the capacity of the river.

Making this site plan housing, developers are generally eager to optimize land use to obtain maximum residential land area, and the orientation of the interesting buildings. For example, the process of making a residential site plan like JNC in Jember Regency requires setting up the Ketandan Creek. Location of housing is flanked by two tributaries to the north is the Rembangan river and to the west is the Ketandan river. Ketandan creek has the function to supply water for irrigation and recharge muddy town. This river has the function to watering for irrigation and recharge of Jember town. However, this land use optimation should not ignore the initial function of the rivers and the ecological damage that exist.

Modification of the natural flow regime dramatically affects both aquatic and riparian species in streams. Ecology respond due to changes in flow regime will

${ }^{1}$ Entin Hidayah, Wiwik Yunarni Widiarti, and Anik Ratnaningsih are with Departement of Civil Engineering, Faculty of Engineering, Universitas Jember, Jember, 68121, Indonesia.

Email: entin_hidayah@yahoo.com; wiwikferi@gmail.com; ratnaningsihanik@gmail.com. affect the process of geomorphic and ecological sustainability (Poff et al. 1997). Settings or displacement in river flow cause changes in the hydraulic characteristics of the stream such as flow depth, discharge, slope, and width of the water surface that have an impact on changes to the flow regime which will affect the sustainability of the ecology of the river.

These processes along the rivers flow paths have various effects on stream properties and habitats (Veihe et al., 2011). Changes in river morphology will alter sediment transport, can cause silting or scouring on the river bottom, or on the cachment area, and can damage waterways, hydraulic structures and the land around the river (Kiesel et al., 2013). But the process of erosion and sedimentation instream also important maintaining the characteristics and function of aquatic ecosystems (Florsheim et al., 2008).

This suggests that there are linkages between the landscape and the setup process for maintaining instream river sedimentation equilibrium. Therefore, displacement flow of Ketandan river and JNC housing arrangement is necessary for an assessment in hydrology and hydraulics to keep the housing from the risk of flooding and maintain ecological sustainability of the river.

\section{METHOD}

\section{A. Study Catchment}

This study was carried out in a small catchment $(2,14$ $\mathrm{km} 2$ ) in the upstream of Rembangan River in Jember Region with UTM projection at $9102000 \mathrm{~N}$ and 9098098 $\mathrm{E}$ (Figure 1). It is drained by a fourth order stream. 
The catchment's topography is undulating with an average slope of $3 \%$. The soil texture is characterised by coarse sandy. Table 1 shows the physiographic conditions of the catchment which area of watershed, the total length of the river, and the slope of the river. Land use for the cachment are farm $(0,39 \mathrm{~km} 2)$, settlement $(0,4 \mathrm{~km} 2)$, housing $(0,17 \mathrm{~km} 2)$, irrigation paddy fields $(1,17 \mathrm{~km} 2)$, and land field / moor $(0,01 \mathrm{~km} 2)$.

\section{B. Hydrology}

The Hydrology modelling is a valuable tool for researchers in geography and other disciplines for studying the runoff signal which leaves the watersheed from the rainfall signal received by the basin. The rainfall-runoff model is one of the most frequently used events in hydrology. HEC-HMS program is one of hydrology models that usually is used to rainfall-runoff modelling. One of option from this progam is SCS curve number. SCS curve number can use to estimate the flood design. The parameters needed in modeling hydrograph with SCS curve number is the curve number $(\mathrm{CN})$, storage at saturation (S), initial abstraction, constant losses, imperviousness, time of concentration, recession constant (HEC, 2000). $\mathrm{CN}$ is used to estimate storage at saturation, $\mathrm{S}$ is the watershed 's ability to hold water when saturated. The relationship between $\mathrm{CN}$ and $\mathrm{S}$ can be formed in equation (1) below.

$\mathrm{S}=\left(\frac{25.400}{\mathrm{CN}}\right)-254(\mathrm{~mm})$

Precipitation input to design river usually is used rainfall design with variation of time periode. To estimate rainfall design, four vary distributions usually is selected like Gumbel, Genelized Extreme value (GEV), Log Pearson type III and 3-parameter Log Normal distributions by L-Moment method like Schoeckelbach basin, Austria (Galoie et. al., 2013). The goodness of fit test is done by RMSE, Chi-Square and SminovKolmogorov. Gumbel's distribution is the best-fit probability distribution.

Discharge treatment as an input in the planning of displacement flow using two conditions, namely in normal and flood conditions. For normal conditions, discharge used is return period of 2 year and for flood conditions, discharge used is return period for 100 years. Flood design event is calculated based on hydrology modelling by HEC-HMS program. The SCS curve number was adopted based on the finding of previous studies in Indonesia. Murtiono, (2008) compared the application of the SCS curve number, Rational and MUSLE. SCS showed the best results. Palar (2013), compare SCS hidrograf with rasional method, and SCS method constitute applicable for DAS Tilaka.

The annual extreme rainfall data from 2004 to 2013 is fitted to proper probability distribution model in order to estimate rainfall quantities. In order to find the best-fit probability distribution model, a parameter estimation tecnique is used and for goodness of fit test using easy-fit program with Smirnov-Kolmogorov test. Comparison between four commonly used rainfall frequency distribution are carried out such as Normal, Gumbel, Log Pearson type III and Log Normal type III. Futhermore, the best-fit probability disribution can be used to determine the intensity-duration frequency relation for Rembangan Creek. The intensity-duration frequency is estimated by Mononobe formula.

\section{Hydrolic Model}

Hydraulics components that influence the flow regime in the open channel include discharge, the dimensions of the river, the slope, roughness manning, velocity, and Froude number. In HEC-RAS, the relationship between these parameters can be described by equations $(2,3,4$ and 5). USACE (2010)

$\mathrm{Q}=\mathrm{F}(\mathrm{A}, \mathrm{R}, \mathrm{S}, \mathrm{n})$

Where $\mathrm{Q}$ is discharge, $\mathrm{A}$ is cross sectional area, $\mathrm{R}$ is hydraulic radius, $\mathrm{S}$ is enegy slope and $\mathrm{n}$ is manning's value. In HEC-RAS, the Manning's equation is the basis for the solution of uniform flow as equation (3)

$\mathrm{Q}=\frac{1,486}{\mathrm{n}} \mathrm{AR}^{2 / 3} \mathrm{~S}^{1 / 2}$

Criteria the critical boundary according to the HECRAS is different than the theory of hydraulics in general. In determining the accuracy of the flow regime, HECRAS has been considering the channel cross-sectional shape irregularity. Water surface flow is classified as critical if the resulting Froude number is greater than 0.94 to 1 and if more than one classified as supercritical (USACE, 2010). Equation of Froude number to determine the level of critical according to Chow (1959) was formulated as equation (4).

$\mathrm{Fr}=\frac{\overline{\mathrm{v}}}{\sqrt{\mathrm{gH}_{\mathrm{D}}}}$

where Fr is Froude number; $g$ is acceleration due to gravity $(9,8 \mathrm{~m} / \mathrm{sec} 2) ; \mathrm{HD}$ is hydrolic depth $=\mathrm{A} / \mathrm{T}(\mathrm{m})$; and $\mathrm{v}=$ velocity rate at the cross cection reach $(\mathrm{m} / \mathrm{det})$. In above equation, $\mathrm{c}$

is the celerity of grafity wave is:

$\mathrm{c}=\sqrt{\mathrm{gHD}}$

If the critical condition, $\mathrm{v}$ value equal to $\mathrm{c}$.

In addition to analyzing the dimensions of the channel, HEC-RAS was able to design the waterworks like dams, drop structure and spillway. Standard equation for weir planning in HEC-RAS used the following approach.

$\mathrm{Q}=\mathrm{CLH}^{3 / 2}$

Where, $Q$ is flow rate; $C$ is weir flow coefficient; $L$ is weir Length; $H$ is weir energy head. Critical condition occurs when the water depth $\left(H_{c}\right)$ above spillway in critical condition. The equation for $H_{c}$ is the relationship between discharge $(q)$ per width $\left(\mathrm{m}^{2} / \mathrm{sec}\right)$ and $g$ as acceleration of gravitation.

$H c=\sqrt[3]{\frac{q^{2}}{g}}$

To verify the flow regime on the critical need to know the depth of the channel cross section associated with the equilibrium elevation. The total energy loss in the channel cross section is defined by equation (8)

$H=W S+\frac{a V^{2}}{2 g}$

where $H$ is the total energy head, $W S$ is the water surface elevation and $\left(a V^{2}\right) / 2 \mathrm{~g}$ is the head speed. Water surface elevation in critical condition if the total minimum energy head (specific energy minimum occurs for a reach cross section).

Hydraulic structures that will be planned in the displacement flow includes the channel cross-sectional shape, dam structure, spillway side and drop structure. With HEC-RAS software, the direction of current flow will be changed to maintain the soil in the form of basic 
channels, and channel banks using stone masonry with a slope of $1 \mathrm{~V}: 0.5 \mathrm{H}$. Schema changes in flow direction can be straightened channel is shown in Figure 2 HECRAS scheme. Channel diversion plan will be maintained from the water surface critical condition.

\section{Storm Monitoring}

One rain gauge should be sufficient for this small catchment. The water level was measures continuously at weir. Discharge over the Ketandan weirs was measured by volumetric gauging during several storm event. A strong correlation between discharge and water level was obtained with coefficient of determination, $r^{2}=0,92$. This level of discharge rating curve was used to convert water levels into discharge value. The discharge record value was used to estimate the parameter of hydrology model. For 2 years return periode is obtained the storm of $3,1 \mathrm{~m} 3 / \mathrm{sec}$ as reference model.

\section{RESULT AND DISCUSSION}

\section{A. Flood design in Ketandan Creek}

Based on Smirnov-Kolmogorov test using easy-fit statistic program at chosen significance level (alpha=5\%), from the four distributions (Normal, lognormal, gumbel, and log-piearson), all of distribution form is accepted because the result of the test statistic, D, is smaller than the critical value. Gumbel is the best-fit probability distribution model because it has the smalest statistic ranking. The result is obtained for the statistic (D) equal to $0.143, \mathrm{P}-$ Value equal to 0.937 and confident interval $\alpha=5 \%$ equal to 0.375 . With L-Moment method, high rainfall estimation results obtained $70,186 \mathrm{~mm}$ for return period of 100 years and 178,981 mm return period of 100 years. The relationship between rainfall intensity with duration is describe in figure 3.

Furthermore, the HEC-HMS obtained peak flow of flood design for 2 year return period of $3,1 \mathrm{~m}^{3} / \mathrm{sec}$ in figure 4 and for 100 return period of $12,8 \mathrm{~m}^{3} / \mathrm{sec}$ in figure 5 .

\section{B. Displacement flow without drop structure}

Based on the results of running the HEC-RAS for the straightening of the river to the discharge of $3,1 \mathrm{~m}^{3} / \mathrm{sec}$ for normal conditions, and discharge of $12,8 \mathrm{~m}^{3} / \mathrm{sec}$ for the design flood conditions by adjusting the slope of the river natural condition. The critical water surface is obtained of 19 sites and in normal condition and of 22 sites in flood condition. (The resulting Froude number ranges from 0,96 up to 1.01) figure 6 and 7. This is show that the higher discharge is flowing, the more critical water surface is occured. The condition generally occurs in a location that is two steep slope of the river, or in the downstream and upstream dam and spillway. This is due to the water velocity is too high, and the water depth in the channel is too low, so that the specific energy produced to be great. Future occurrence of scouring in the river bed will probably happen. In anticipation of this event, a large decrease in specific energy is very important. A structure that is able to protect the base line or reduce specific energy will be very necessary.

\section{Displacement flow with Drop Structure}

Furthermore, in anticipation of a large specific energy, some waterworks need to be built like a drop of water along with a stilling basin as energy absorbers. In the upstream weir need 2 drop structure, between the downstream of Ketandan weirs to side spillway requires 5 drop structure, and downstream side spillway needs 3 drop structure (Figure 8 and Figure 9). From the results of running the HEC-RAS by adding waterwork to river bed, resulting Froude number is less than 0, 94.

\section{CONCLUSION}

Gumbel's distribution probality is the best-fit for rainfall design in Ketandan basin.

HEC-RAS results of running a program using the normal discharge of $3,1 \mathrm{~m}^{3} / \mathrm{sec}$ and storm of $12,8 \mathrm{~m}^{3} / \mathrm{sec}$, for straightening the Ketandan river. The critical water surface is obtained of 19 sites for the normal discharge and 22 sites for storm condition.

Furthermore, if the locations of the critical water surface constructed drop structure and stilling basin, the status of the flow regime of river will be a sub-critical.

\section{REFERENCES}

[1] V. T. Chow, Open Channel Hydraulic, New York USA: McGrawHill Book, 1959.

[2] M. Galoie, G. Zenz and A. Motamedi, "Rainalisis for the Schoeckelbach Basin (Austria) and Determining its Best-Fit Probability Distribution Model," in 6th International Conference on Water Resources and Environment Research (ICWRER), Koblenz, Germany, 2013.

[3] J. Kiesel, B. Schmalz, G. L. Brown and N. Fohrer, "Application of A Hydrological-Hydraulic Modelling Cascade in Lowlands for Investigating Water and Sediment Fluxes in Catchment, Channel And Reach," Journal of Hydrology and Hydromechanics, vol. 61, no. 4, pp. 334-346, 2013.

[4] U. H. Murtiono, "Kajian Model Estimasi Volume Limpasan Permukaan, Debit Puncak Aliran, dan Erosi Tanah dengan Model Soil Concervation Service (SCS), Rational dan Modified Universal Soil Loss Equation (MUSLE) (Studi Kasus di DAS Keduang, Wonogiri)," Forum Geografi, vol. 22, no. 2, pp. 169-185, 2008.

[5] G. W. Brunner, HEC-RAS River Analysis System, Hydraulic Reference Manual, Version 4.1, Davis, California, USA: U.S. Army Corps of Engineers, 2010.

[6] A. Veihe, N. H. Jensen, I. G. Schiotz and S. L. Nielsen, "Magnitude and Processes of Bank Erosion at A Small Stream in Denmark," Hydrological Processes, vol. 25, no. 10, p. 1597-1613, 2011.

[7] T. R. Palar, L. Kawet, E. M. Wuisan and H. Tangkudung, "Studi Perbandingan antara Hidrograf SCS (Soil Conservation Service) dan Metode Rasional pada DAS Tilaka," Jurnal Sipil Statik, vol. 1, no. 3, pp. 171-176, 2013.

[8] L. N. Poff, J. D. Allan, M. Bain, J. R. Karr, K. L. Prestegaard, B. D. Richter, R. N. Sparks and J. C. Stromberg, "The Natural Flow Regime: A Paradigm for River Conservation and Restoration," BioScience, vol. 47, no. 11, pp. 769-784, 1997. 


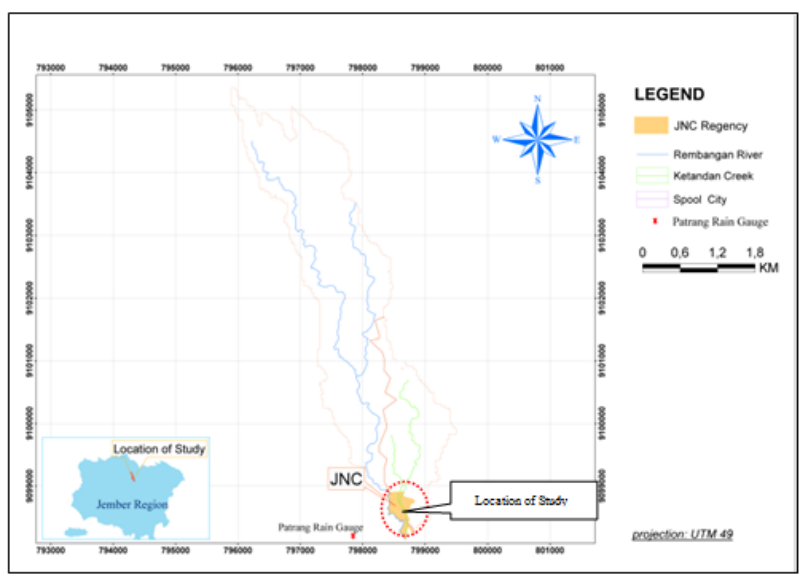

Figure 1. Location of study

Natural flow

Displacement flow

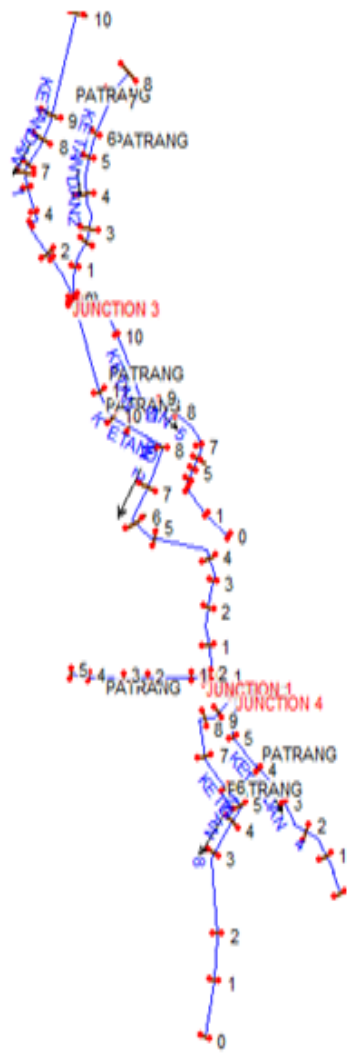

Figure 2. Scheme of HEC-RAS

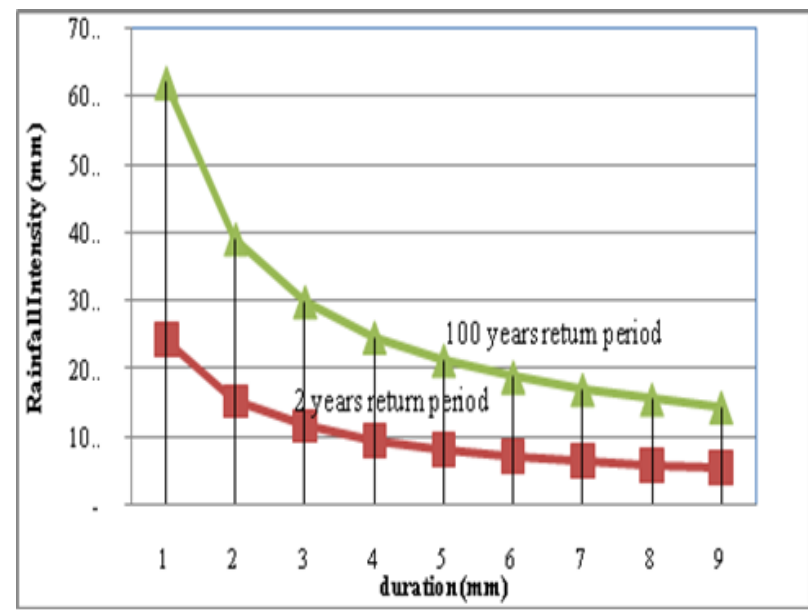

Figure 3. Rainfall intensity
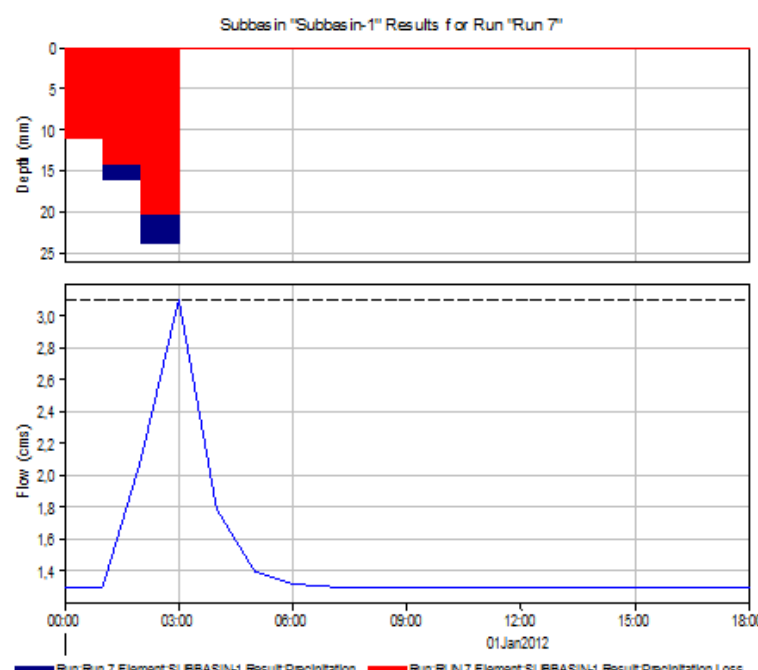

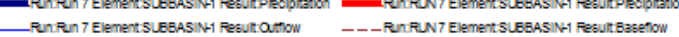

Figure 5. Normal Condition
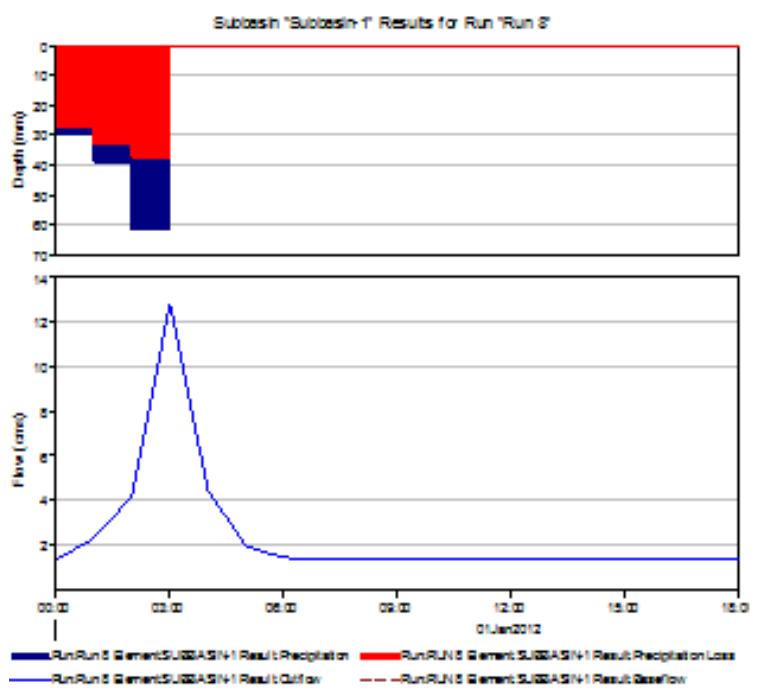

Figure 5. Flood Condition

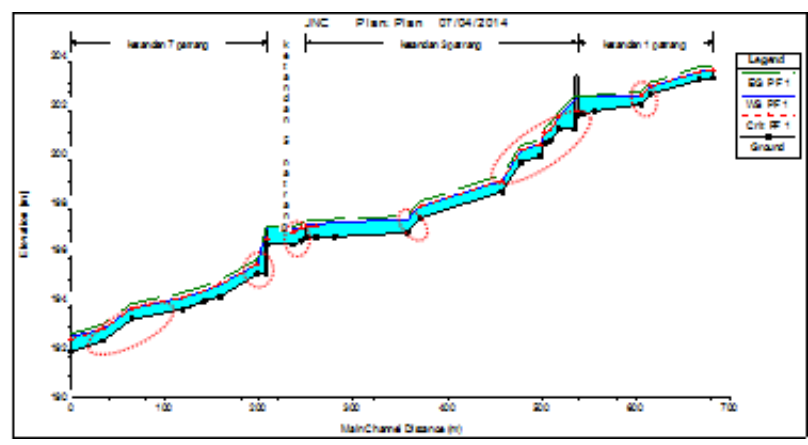

Figure 6. Normal condition without drop structure

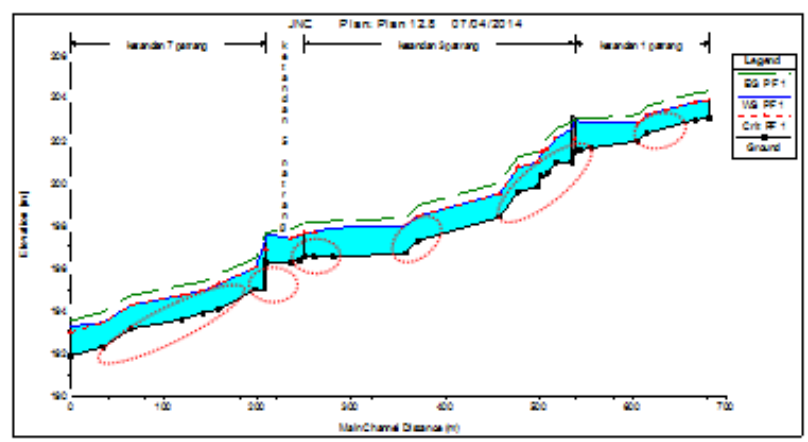

Figure 7. Flood condition 


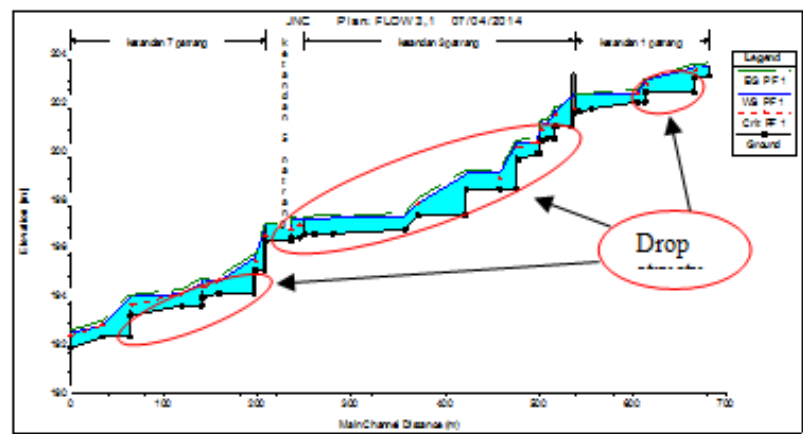

Figure 8. Normal condition with drop structure

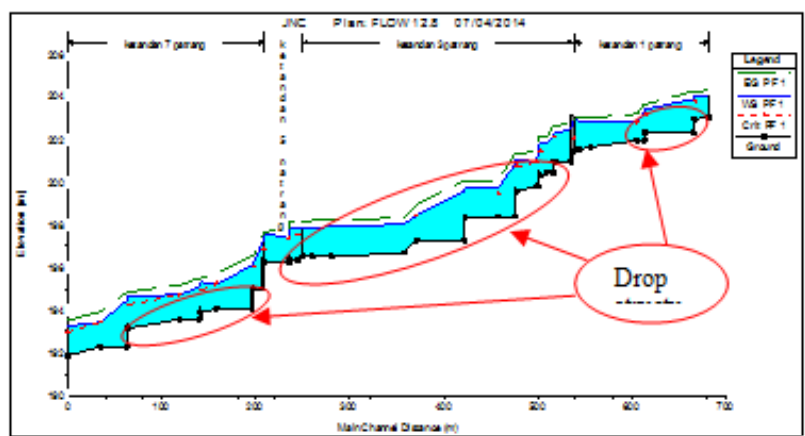

Figure 9. Flood condition drop structure 